\title{
On \\ Dolly and the scandalous nature of life sciences and Where bioethics really begins*
}

\author{
Gregor Becker $\bowtie$ \\ Department of Biophysics, Faculty of Biochemistry, Biophysics and Biotechnology, Jagiellonian University Kraków, Kraków, Poland
}

In memoriam Lewis Wolpert

25 years ago, Dolly the sheep and the cloning issue stood in the focus of widespread and heated societal and ethical discussions that, for the bigger part, were not rational. In the aftermath of Dolly, in Europe bioethics was established as a discipline that is hyper-sceptical critic of science. Bioethics seen from the point of view of science is nebulous to many researchers, such as Lewis Wolpert, who called bioethics "a gross load of nonsense". It appears that the image of science in bioethics and society has as much suffered and moved away from the factual truth, as the image of bioethics and society has suffered in science since the Dolly event. It is time to return to a reasonable view of science, bioethics and society - and of Dolly the sheep.

Keywords: Dolly, cloning, bioethics, Lewis Wolpert

Received: 29 September, 2021; revised: 09 October, 2021; accepted: 09 October, 2021; available on-line: 14 November, 2021

$\square_{\text {e-mail: gregor.becker@uj.edu.pl }}$

*This paper has been published on the occasion of Jubilee Conference entitled "The latest achievements in biochemistry, biophysics and biotechnology - 50 years of history of the Faculty of Biochemistry, Biophysics and Biotechnology of the Jagiellonian University in Kraków" Kraków, September 23-24, 2021.

"And then there was an enormous fuzz on cloning cloning a human being. (...)

There were people being hysterical on the ethical issues that this raises.

I have to tell you that I have offered on television, the radio and the press a bottle of champagne to anybody who could show me or tell me one new ethical issue that this raises.

There is a further complication: if you come and ask for your bottle of champagne, and I show you that you are wrong and it's not new, you have to give me two. Nobody has ever come forward to ask for their bottle of champagne.

In other words: (...) Bioethics (...) it is really a gross load of nonsense.

Safety, of course, and if you're doing experiments on animals, you must try that they may not suffer too much pain, and if you're doing experiments with people, you have to tell them what you're actually doing, but I think the ethical issues related to the early human embryo and cloning simply have no foundation whatsoever."

Lewis Wolpert (Wolpert, 2016)

(Lewis Wolpert (1929-2021) was a South-African embryologist and developmental biologist, working at the University College London. Inter alia, he became famous for his naïve-positivist view on science connected to aggressively formulated but also entertaining critiques of bioethics.)

In 2021, the Faculty of Biochemistry, Biophysics and Biotechnology of the Jagiellonian University celebrates its 50 years anniversary. 25 years ago, during my first visit in Kraków, the idea of bioethics getting integrated into life sciences at the Jagiellonian University came up. In the same year, 1996, a prodigious event in science paved the way for contemporary bioethics in Europe, as well as for the project of Integrated Bio-Ethics in Kraków.

One cannot talk about the future of bioethics without mentioning the "tremendous" recent past of life sciences - when people got downright bysteric on ethical issues of cloning a human being - as Wolpert expressed it neatly.

It all began with a very special, but by appearance not at all monstrous, Scottish sheep.

When on July 5, 1996, for the first time in her life the sheep that was so different to all other sheep but one, saw the light of day, it was probably the stone-cold white light of a 60 -W att Osram neon tube in a laboratory (Grass, 1960).

The reactions to Dolly's existence, on the other hand, were anything else but cold.

When the message on her existence went viral, Dolly veritably scared the living daylights out of the world.

Dolly provoked a strange mixture of very emotional reactions, ranging from extremely alarmed moral remarks to hectic political initiatives, and from "hysteria simplex" to doomsday moods. The situation was as tense as if the first rider of the Apocalypse appeared on a sheep, announcing Armageddon to be ante portas.

In a fit of exaggeration, Lee Silver, a biology professor at Princeton University said: 'It's unbelievable. It basically means that there are no limits. It means all of science fiction is true (Kolata,1997). And in a blink of an eye, US president Bill Clinton prepared hectically prepared a law prohibiting cloning, not of sheep but humans (Wadman, 1997). Dolly was produced just in time and, although the first cloned being was not a biped, the UNESCO could just squeeze in a respective Article 11 on cloning humans in its Universal Declaration on the Human Genome and Human Rights (UNESCO, 1997).

Dolly made it also down to lower societal levels.

In an advertisement, the Italian producer of home appliances, Zanussi, changed its well-known slogan from "The Appliance Of Science" to "The Mis-Appliance Of Science": showing the photo of an imposter Dolly-thesheep (Watson-Smyth, 1998). The inventors of Dolly felt 
so much attacked and provoked by this moral critique that they publicly contradicted Zanussi.

I could not find any other example - neither for science reacting to an advertisement nor for any bioethical critiques launched towards science by a home appliances producer.

Proving the existence of the better angels of British humour, on February 27, 1998, the Dolly front page of the yellow press newspaper THE SUN consisted of two identical pages, printed side by side on the same sheet: the original front page, and the "cloned" one. THE SUN's headline was "CLONE SHOCK", and it was an innuendo to the "Sputnik shock", as the "shock of the century” (Dickson, 2003).

In a fit of nerdy humour, as an "old boys' joke", the inventors of Dolly named her after Dolly Parton because the DNA for cloning was derived from mammary gland cells. Dolly Parton took it with humour: "I never met her, but I always said there's no such thing as baad publicity" (Shanks, 2019).

The greatest joke of all was, however, that the scandalous case of Dolly is based on two simple, but nevertheless often disregarded facts: Dolly is just a lab-made twin, and no serious scientist spoke about cloning humans.

Within science, after decades of experiments in vain, the first cloned mammal was surely a positive sensation. Nevertheless, the enthusiasm of the inventors of Dolly on their invention was neither shared publicly by a bigger number of their peers, nor do publications in scientific and other journals significantly mirror any support of them when Dolly shifted them into the focus of a public scandal.

However, shortly after Dolly's birth, Lee Silver has published a book entitled "Remaking Eden" (Silver, 1998), in which he supports both, cloning and genetic engineering, in humans. Rather curious fellows, not too well known for their scientific work but more for their ambitions to stand in the spotlight, such as Richard Seek (1998), Severino Antinori (2002), Brigitte Boisselier (2002), Panos Zavos (2004), and Woo Suk Hwang (2004) announced each to have cloned a human being, without delivering any proof for it (Alcíbar, 2013). The popular Oxford biologist and "leading British scientist" (BBC, 1999) Richard Dawkins explained that he had nothing against cloning his daughter, for the clone would be nothing else but a twin of his offspring.

Later, the meaning on the research that led to Dolly has been appreciated in science due to its meaning for stem cell research. Nobel Prize laureate Shinya Yamanaka confirmed personally "that Dolly's cloning motivated him to begin developing stem cells derived from adult cells" (Weintraub, 2016). After receiving the Nobel Prize, in an interview with the BBC, "the Godfather of cloning" (Williams, 2008), Sir John Gurdon presumed that cloning humans may become acceptable in society once its medical meaning becomes visible.

Recent public statements on Dolly by scientists and the lack of any societal or ethical outcry may indicate that the issues of the sheep and the perspective of human cloning are not any more as "radioactive" as they were in the late 1990ies, but they have lost a lot of their radiation in the cooling pond of time. It may appear that cloning has become a normal scientific topic. Whether the same approach will be seen in society and in science when the first cloned human gets announced is, however, extremely doubtful.

Dolly may have been the sheep of contention, but although back in the days, no serious scientist said any word about it, it was assumed at once that all science aims to clone humans. It was claimed that by creating Dolly, science has allegedly crossed the moral Rubicon and that it has turned into so-called "Frankenstein-science" (Hellsten, 2009).

The insulting allegation against life sciences, to have done an unnatural, perverted and monstrous thing is discussable. It is apparent that this accusation originates from the yuck factor (Kass, 1997) of a cute animal, born not on straw in a cosy Shaun-the-sheep-barn, but in a tiled laboratory. For people who do not understand the science of Dolly and ignore the reality of modern animal breeding, Dolly must appear monstrous, and her inventor to be Dr Frankenstein.

Moral repugnance based on disgust is not rational. It is something in the eye of the individual beholder (or maybe more: in their stomach). If moral repugnance was acknowledged as a suitable indicator for an ethical status of something, then anything causing disgust in some people could be called unethical: e.g., an appendix operation with a lot of blood, two men kissing each other, or broccoli. That is nonsense.

Emotions, feelings, hunches, or an itching occiput may be a good start in evaluating things, even in ethics: when not all facts of a case are clear, yet. After a "moment of shock and awe" however, instincts, intuitions and the gut feeling need to get reflected and rationalised.

In the end, however, associations of science with horror stories may be somehow striking and entertaining, but they do not clarify any ethical issues.

Should the creators of Dolly have considered the possibility that one day in the future, their cloning-technique may be possibly used for cloning humans?

They did, and Jaenisch and Wilmut have already concluded in the title of their paper: "Don't clone humans!" (Jaenisch, 2001) - because the failure rate of the "Dollycloning technique" is too high to be acceptable in human experiments.

Interestingly, in the final sentences in their paper, they quasi relativise the strong exclamation mark in the title, creating the impression that a ban on cloning humans is a kind of just temporary categorical imperative: "In the United States, the National Bioethics Advisory Commission reached that conclusion 5 years ago. "At present, the use of this technique to create a child would be a premature experiment that would expose the foetus and the developing child to unacceptable risks." All the data collected subsequently reinforce this point of view."

In plain text, it means that an improvement in cloning techniques may become a game changer in terms of cloning humans.

There are a lot of reasonable moral questions concerning cloning but the discussions on Dolly and cloning humans were mainly not reasonable - with consequences that are effective until today.

If there is one event in life sciences that has created the specific image, science now enjoys in bioethics, then it is "Dolly the cloned sheep". If there is one event in life sciences that has created the specific character of bioethics today, then it is also "Dolly the cloned sheep".

Dolly was a PR disaster for science, and not a triumph. The calls for control over sciences were never louder than in the aftermath of Dolly. Dolly seemed to be the proof that life scientists "play God" with the building blocks of life. Maybe the Roslin Institute chose just the wrong way to present their scientific success, but they obviously aimed at standing in the public spotlight, and maybe even on the Nobel Prize. If it was their idea to create fame with shocking science news, it backfired 
tremendously, and they have done science a huge disservice.

If it was just cells that were cloned, or a hypothesis that was confirmed in a petri-dish experiment, maybe then the cloning success would not have been noticed at all by the hypersensitive public (and also bioethicists), taking sensations in life sciences rather with shock than with awe.

The fact stays that life sciences have reaped the whirlwinds of "ethical" outrage that were sowed when they presented the first lab-cloned mammal as a real being and they screamed loudly that "it's alive!".

The real "monstrosity" of Dolly the cloned sheep, however, is to be seen in the success of wresting the exclusive competence in reproduction from nature, and to put that into human hands. But is that not what all science and technology is about: humanity learning from nature and to get more and more competent on our own? If so, then in science we shall better get prepared for creating societal and bioethical outcries, we also henceforth will create with our successes.

All bioethical doubt and public suspicion against life sciences are not primarily of moral nature. Behind moral irritations that modern life sciences create, there is fear; the fear that humans might be overwhelmed by answering wisely and responsibly to the moral questions that come along with the growing power of life science over life.

When all life was a passive object of nature that was given final verdicts from nature beyond good and evil, humanity could disregard this enormous moral challenge Now humanity cannot flee any more from the responsibility for answering the questions of what to do with the power over life. It is too late for that.

The question, however, I would like to ask is this one:

In any way, can it be morally wrong that science and technology frees us from the existential prison of natural determination, and to take our genetic and reproductive fate into our own hands?

Wolpert was right: bioethics does not ask anything new, but from where Wolpert took the idea of novelty in bioethics remains a mystery to me. In essence, bioethics is incapable of coming up with new ethical questions, but it has never ever claimed that it could!

The point is not if bioethics has new questions to ask, the point is that scientific developments raise old questions that need new answers.

The answers from then may not fit the circumstances of now. We need to rethink them every time science and technology come up with new knowledge and techniques. That's the way it is. Seen this way, bioethics is a "déjà-vu discipline" dealing with "Zombie-questions" that are never "dead" and finally answered.

Wolpert claimed that bioethics shall restrict itself to "safety issues".

That is quite a petty approach considering the big breakthroughs in science that sooner than later will make it necessary to do more experiments and more trials on more humans and more animals than ever before - and numerous other questions than just the safety-questions will come up.

Wolpert's specific idea of bioethics as a kind of "safety-lock" of science is also insufficient for other reasons.

The impression that bioethics deals solely with big issues may ironically originate from bioethics, showing off with its alleged extreme importance.

However, bioethics actually begins with issues in a frame that are way less dramatic than questions on life and death, but not less important.
How can science do the right things right?

Social issues of doing science, such as civilised collaborations, concern us here first. The very term "civilised collaborations" imputes to its Latin origin with the meaning "decent teamwork". It is involved in issues about which not just ethics and Christian theology are concerned. In fact, civilisation and scientification have advanced together.

One axiom of ethics means that "the ethical dimension begins when the other appears on the scene" (Eco, 2002, P19), and since doing science is working with others, science includes a priori an ethical dimension.

The truth of bioethics is not just out there. As an internal affair of life sciences, bioethics needs to get discovered and worked out where science is done. How to... is what we need to think about. As supplementary material to this article, I have attached a set of rules mainly for science students to this article: not for the students to follow them blindly, but to think about what they are doing.

\section{REFERENCES}

Alcíbar M (2013) The Presentation of Dolly the Sheep and Human Cloning in the Mass Media. Intech Open. https://doi. org $/ 10.5772 / 56161$

BBC NEWS (1999) Nothing wrong with clones says Dawkins. https:// news.bbc.co.uk/2/hi/science/nature/265878.stm

BBC RADIO (2012) Interview with John Gurdon. https://www.bbc. co.uk/programmes/b01p9ks8

Eco U (2002) Five moral pieces. Harvest Book Harcourt, Inc., San Diego

Dickson P (2003) Sputnik: The Shock of the Century. The Berkley Publishing Group, New York

Grass G (1979) Blaszany bębenek. Państwowy Instytut Wydawniczy, Warszawa (in Polish)

Hellsten I (2009) Dolly: Scientific Breakthrough or Frankenstein's Monster? Journalistic and Scientific Metaphors of Cloning. In Metaphor and Symbol 15/4: 213-221. https://doi.org/10.1207/ S15327868MS1504_3

Jaenisch R (2001) Don't clone humans! Science 291/5513: 2552. https://doi.org/10.1126/science.1060463

Kass L (1997) The wisdom of repugnance. https://www.pbs.org/ wgbh/pages/frontline/shows/fertility/readings/cloning.html

Kolata G (1997) Scientist report first cloning ever of adult mammal. The New York Times, February 23, 1997. https://www.nytimes. com/1997/02/23/us/scientist-reports-first-cloning-ever-of-adultmammal.html

Silver L (1998) Remaking Eden. How Genetic Engineering and Cloning Will Change The America Family. HarpPeren, New York

Shanks P (2019) Born This Week: Dolly the Sheep. Center of genetics and society, Biopolitical Times, 2019-03-07. https://www.geneticsandsociety.org/biopolitical-times/born-week-dolly-sheep

UNESCO (1997) Universal Declaration on the Human Genome and Human Rights. https://portal.unesco.org/en/ev.php-URL ID=13177\&URL DO=DO TOPIC\&URL SECTION=201.html

Wadmann M (1997) White House bill would ban human cloning. $N a$ ture 387: 644. https://doi.org/10.1038/42560

Watson-Smyth K (1998) Dolly makes a mark in commercial world. In Independent, 1998-09-09. https://www.independent.co.uk/news/ dolly-makes-a-mark-in-commercial-world-1197082.html

Williams Ruth (2008) Sir John Gurdon: Godfather of cloning. I Cell Biol 181: 178-179. https://doi.org/10.1083/jcb.1812pi

Weintraub K (2016) 20 Years after Dolly the Sheep Led the Way Where Is Cloning Now? Cloning has had a bigger impact on science, but a smaller one on human life, than many expected. https://www.scientificamerican.com/article/20-years-after-dolly-thesheep-led-the-way-where-is-cloning-now/

Wolpert L (2017) The nonsense of bioethics, part 26/36. https:// www.youtube.com/watch?v=FvMHLky_XGY 